\title{
PHOTOSENSITIVITY OF CUCUMBER (Cucumis sativus L.) SEEDLINGS EXPOSED TO ULTRAVIOLET-B RADIATION
}

\author{
María Luisa Tapia F. ${ }^{1}$, Guillermo Toro A. ${ }^{1}$, Bélgica Parra R. ${ }^{1}$, and Alejandro Riquelme E. ${ }^{1}$
}

\begin{abstract}
The intensity of ultraviolet-B radiation (UV-B) has increased on the Earth's surface due to the stratospheric ozone depletion, causing an adverse effect on a wide range of species, such as morphological, physiological, and biochemical alterations. This research studied the intraspecific photosensitivity of cucumber (Cucumis sativus L.) seedlings exposed to UV-B. Six commercial cultivars were evaluated: Laura, Sprint 440, Dasher II, Exocet, Poinsett 76, and Marketmore 76 under greenhouse-controlled environmental conditions with a hydroponic sandwich-type system with a Hoagland II nutrient solution. Seedlings were irradiated from expanded cotyledons to the third true leaf with three intensities of UV-B radiation $\left(30,40\right.$, and $\left.50 \mu \mathrm{W} \mathrm{cm}{ }^{-2}\right)$ for $18 \mathrm{~d}$ between 11:40-15:40 h. Seedling growth, morphology, accumulation of photosynthetic pigments, and absorbing UV-B pigments were evaluated. 'Laura' was the least affected by chlorosis and had a total absence of leaf curl, whereas 'Poinsett 76' was the most

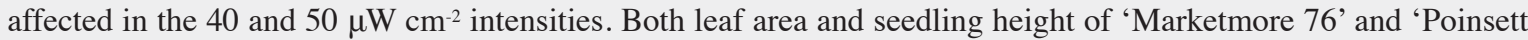
76' had the lowest values. 'Laura' obtained the highest value in both fresh weight and dry weight. 'Poinsett 76' had the least amount of pigments absorbing UV-B and was 53\% lower than that obtained by 'Laura'. 'Poinsett 76' had lower chlorophyll and carotenoids. Parameters used were indicators of the seedling response to UV-B radiation, but could not be used for cucumber seedling sensitivity to UV-B radiation.
\end{abstract}

Key words: UV radiation, Cucumis sativus, chlorophyll, UV-B absorbing compounds, chlorosis.

\section{INTRODUCTION}

The increase of ultraviolet-B (UV-B) radiation levels on the Earth's surface, especially at the poles (Cabrera et al., 1995) has provoked damage in ecosystem primary producers (WMO, 2007). This increase is due to chlorofluorocarbon compounds (CFCs), which appeared in the 1930s having the main characteristic of high stability, volatility, and a high affinity with ozone (natural filter of UV-B radiation). This initiated the partial destruction of the stratospheric ozone layer detected in the 1970s (Rowland, 2006; WMO, 2007). However, even though the majority of these compounds are not currently used, the destructive process has not been reverted (McKenzie et al., 2003). Regarding latitude, variations have originated in the total ozone thickness that increases from North to South in Chile, and of the influence of latitude on the sun's cenital angle. A decrease in UV-B

'Universidad de Chile, Facultad de Ciencias Agronómicas, Casilla 1004, Santiago, Chile. "Corresponding author (mtapia@uchile.cl). Received: 30 December 2008.

Accepted:11 May 2009. radiation from North to South is expected due to both factors (Cabrera et al., 1995).

The increase in UV-B radiation causes damage in plants by negatively affecting photosynthesis and changing pigment content, photosynthetic pigments as well as those which are a UV-B filter in the epidermis, altering leaf area and plant height, biomass distribution, flowering time, and crop yield (Jansen et al., 1998; Zhao et al., 2003; Kakani et al., 2003).

Plants have developed protection mechanisms against the high levels of UV-B radiation such as the synthesis of flavanoids and other phenolic compounds (Musil et al., 2002; Frohnmeyer and Staiger, 2003). These compounds are accumulated in the epidermal and mesophile tissues (Hollósy, 2002) decreasing the damage in the photosynthetic apparatus and in the DNA (Mazza et al., 2000). This type of protection has been studied in numerous species of which several are cited: quinoa (Chenopodium quinoa Willd.) (Hilal et al., 2004), potato (Solanum tuberosum L.) (Santos et al., 2004), soy (Glycine $\max$ [L.] Merr.) (Mazza et al., 2000; Feng et al., 2003), broad bean (Vicia faba L.), radish (Raphanus sativus L.) (Zavala and Botto, 2002), and cucumber (Cucumis sativus L.) (Hunt and McNeil, 1998; Krizek et al., 2001). 
It is interesting to recognize UV-B radiation sensitivity in $C$. sativus plants since numerous negative effects have been observed, such as growth inhibition (Takahashi et al., 2002; Zavala and Botto, 2002), decrease in height and dry weight of the aerial part (An et al., 2004), formation of chlorotic wounds in the leaves (Krizek et al., 1993), and the reduction of the quantity of total photosynthesizing pigments (Krizek et al., 2001). Differences in sensitivity between cultivars of the same species have been shown in diverse studies such as Kumagai et al. (2001) who determined intraspecific differences between two rice (Oryza sativa L.) cultivars in the presence of an increase in UV-B radiation, presenting differences near $46 \%$ in the accumulation of dry matter. On the other hand, Pinto et al. (2000) found differences in plant dry weight between wheat (Triticum aestivum L.) varieties.

This study proposes the existence of different degrees of sensitivity to UV-B radiation among cucumber cultivars that can possibly be detected in early stages of phenological development. The objective of this study was to determine photosensitivity in view of the increase of UV-B radiation of seedlings from six cucumber cultivars by evaluating growth and morphological parameters, and the accumulation of both photosynthetic and UV-B absorbing pigments.

\section{MATERIALS AND METHODS}

\section{Growth conditions and plant growth}

The study was carried out on cucumber seedlings between February and April 2004 in the Faculty of Agricultural Sciences of the Universidad de Chile, Santiago. The maximum intensity of photosynthetically active radiation (PAR) in the greenhouse during the period under study was approximately $785 \mu \mathrm{mol} \mathrm{m}^{-2} \mathrm{~s}^{-1}$ (LI-190, Li-Cor, Lincoln, Nebraska, USA). Maximum and minimum mean temperatures were 28 and $14{ }^{\circ} \mathrm{C}$, respectively, with a relative humidity of $60 \%$. Seeds from six cultivars were used: Laura (L), Sprint 440 (S), Dasher II (D), Exocet (E), Poinsett $76(\mathrm{P})$, and Marketmore $76(\mathrm{M})$, all of which were left to germinate in a chamber at $25{ }^{\circ} \mathrm{C}$ for 2 days. Once the seeds had germinated, homogeneous seedlings were visually selected and established in a hydroponic sandwich-type system (Faúndez, 2004) and maintaining a distance of $2 \mathrm{~cm}$ between each seedling. To acclimatize the seedlings to the hydroponic system, they were maintained only with water for $5 \mathrm{~d}$, and then the water was replaced by a Hoagland II nutrient solution (Hoagland and Arnon, 1950; Lau et al., 2006) diluted $50 \%$ and automatically oxygenated by an air compressor, four times a day for $15 \mathrm{~min}$. After $3 \mathrm{~d}$ of acclimatization, seedlings reached the expanded cotyledon stage and UV-B radiation was applied with four UV-B 313 lamps
(Q-Panel Lab Products, Cleveland, Ohio, USA) for $4 \mathrm{~h}$ per day concentrated in the noontime sun (11:40-15:40 h) until the fourth real leaf stage. Two types of filters were applied, $0.1 \mathrm{~mm}$ thick mica (Socomisch, Santiago, Chile) in each lamp to filter UV-C radiation and a $0.18 \mathrm{~mm}$ thick Mylar filter (GMS, Santiago, Chile) for the control treatment which eliminated minor wavelengths at $320 \mathrm{~nm}$ (Lau et al., 2006). Both filters were changed weekly.

Each experimented UV-B radiation intensity (30, 40, and $50 \mu \mathrm{W} \mathrm{cm}^{-2}$ ) was obtained by locating the seedlings at different distances from the emission source, and intensity was measured with a UV radiometer (Solar Light Co., Philadelphia, Pennsylvania, USA). A randomized complete block design was applied with a factorial structure of $4 \times 6$ and four replicates. The first factor corresponded to the three UV-B radiation intensities plus the control (without UV-B), whereas the second factor corresponded to the six cultivars. ANOVA and Duncan multiple range test $(\mathrm{p} \leq 0.05)$ were applied. Ten seedlings were measured for each replicate of which eight were measured for morphological, growth, color, and leaf anomaly variables, while the remaining two were for leaf pigment measurements.

\section{Evaluation of damage}

Color of the $1^{\text {st }}, 2^{\text {nd }}$, and $3^{\text {rd }}$ real leaves of a seedling were visually determined for each replicate by the Munsell color chart $18 \mathrm{~d}$ after the start of the treatments. A visual evaluation scale for chlorosis and leaf curl was created for indicating the presence or absence of damage (Table 1).

\section{Growth and morphological parameters}

Seedlings were harvested $18 \mathrm{~d}$ after the start of the treatments. Leaf area of two seedlings was measured with a leaf area meter (LI-3050, Li-Cor, Lincoln, Nebraska, USA). The height of two seedlings was measured from the neck to the apex with a millimeter ruler. A seedling was separated in its aerial and root part to determine dry matter and each part was then dried in a forced air heater at $70{ }^{\circ} \mathrm{C}$ until constant weight. Both fresh and dry matter was weighed on a precision scale (AAA 100L, Adam

Table 1. Evaluation scale of presence and percentage of chlorosis in the leaves of seedlings exposed to UV-B radiation.

\begin{tabular}{ll}
\hline $\begin{array}{l}\text { Chlorosis } \\
\text { (category) }\end{array}$ & \multicolumn{1}{c}{ Description } \\
\hline 1 Absent & $\begin{array}{l}\text { Chlorosis not present } \\
\text { Less than } 25 \% \text { of leaf blade }\end{array}$ \\
2 Slight & Between $25-50 \%$ of leaf blade \\
3 Moderate & Between $51-75 \%$ of leaf blade \\
4 Severe & More than $75 \%$ of leaf blade \\
5 Very severe &
\end{tabular}


Equipment, Danbury, Connecticut, USA). All the leaves of a seedling from each replicate were visually evaluated to determine the number of live and dead leaves, and a leaf was considered dead when it had a leaf area with more than $25 \%$ necrosis.

\section{Concentration of UV-B absorbing compounds and flavonoids}

The concentration of UV-B absorbing compounds and flavonoids was determined on a $0.785 \mathrm{~cm}^{2}$ disc of the first real leaf of a seedling by the method Robberecht and Caldwell (1978) described. Pigment extraction was carried out by submerging the sample in a $3 \mathrm{~mL}$ solution of methanol:water: $\mathrm{HCl}\left(79: 20: 1 \%\right.$ v/v) at $4{ }^{\circ} \mathrm{C}$ with constant shaking and darkness for $30 \mathrm{~min}$. Supernatant absorbance at 300 and $360 \mathrm{~nm}$ (absorbing compounds and flavonoids, respectively) were determined with a spectrophotometer (Shimadzu UV-1601, Kyoto, Japan).

Concentration of chlorophyll $a$ and $b$, and carotenoids The concentration of chlorophyll $a$ and $b$, and carotenoids was extracted from a $0.785 \mathrm{~cm}^{2}$ disc of the first true leaf of a seedling. The sample was macerated with $2 \mathrm{~mL}$ of ethanol $(96 \% \mathrm{v} / \mathrm{v})$ and then centrifuged at $10000 \mathrm{~g}$ for $2 \mathrm{~min}$, separated from the supernatant to measure its absorbance (A) at 665 and $470 \mathrm{~nm}$ (chlorophyll $a$ and $b$, and carotenoids) with a spectrophotometer (Shimadzu UV-1601, Kyoto, Japan). Pigment concentration per unit of area was calculated by the equations published by Lichtenthaler and Wellburn (1983):

Chlorophyll $a$ or Chl $a\left(\mu \mathrm{g} \mathrm{mL}^{-1}\right)=13.96 \mathrm{~A}_{665}-6.88 \mathrm{~A}_{649}$ Chlorophyll $b$ or Chl $b\left(\mu \mathrm{g} \mathrm{mL}^{-1}\right)=24.96 \mathrm{~A}_{649}-7.32 \mathrm{~A}_{665}$ Carotenoids or $\mathrm{Cx}+\mathrm{c}\left(\mu \mathrm{g} \mathrm{mL}^{-1}\right)=\left(1000 \mathrm{~A}_{470}-2.05 \mathrm{Chl} a\right.$ $-114.8 \mathrm{Chl} b) / 245$

\section{RESULTS AND DISCUSSION}

\section{Symptomology and damage}

The cultivars Laura, Sprint, and Exocet presented less than $25 \%$ of chlorosis on the leaf blade in all the tested intensities (30, 40, and $50 \mu \mathrm{W} \mathrm{cm} \mathrm{cm}^{-2}$ ) which would indicate slight damage in these cultivars. 'Marketmore 76' was only slightly affected at the $50 \mu \mathrm{W} \mathrm{cm}{ }^{-2}$ intensity. On the other hand, the Dasher II and Poinsett 76 cultivars were the most affected by UV-B radiation with slight to moderate damage for 'Dasher II' and moderate to severe in 'Poinsett 76' along with greater damage in its first and second real leaf (Table 2). Similar results were found by Kramer et al. (1991) and Krizek et al. (1993), indicating cv. Poinsett as the most sensitive of their assays showing internervial and marginal leaf chlorosis. Damage observed in the formed first true leaves was mainly due to the greater exposition time to UV-B radiation as compared to the new leaves that were exposed for less time to this radiation, leaf damage being highly dependent on exposure time (Borisova et al., 2001). In assays carried out by Kramer et al. (1991) and Krizek et al. (1993) in cucumber cvs. Poinsett (sensitive) and Ashley (tolerant), leaf marginal and internervial chlorosis in both cultivars was observed, once again greater in 'Poinsett 76'. This symptomatology was also observed in this study (Figure 1).

The cultivars Laura and Marketmore 76 were not affected by damage in the distinct UV-B radiation intensities with regards to leaf curl, whereas 'Sprint 440', 'Dasher II', 'Exocet', and 'Poinsett 76' were the most sensitive. However, the presence of leaf curl behaved differently in these cultivars in accordance with the UV-B radiation levels (Table 3). Of the most sensitive cultivars, Poinsett 76 was the most affected presenting complete curl of the leaf blade (Figure 1). This symptomatology is associated with the reduction of cellular expansion in determined zones of the leaf blade by auxin photodestruction (Nogués et al., 1998).

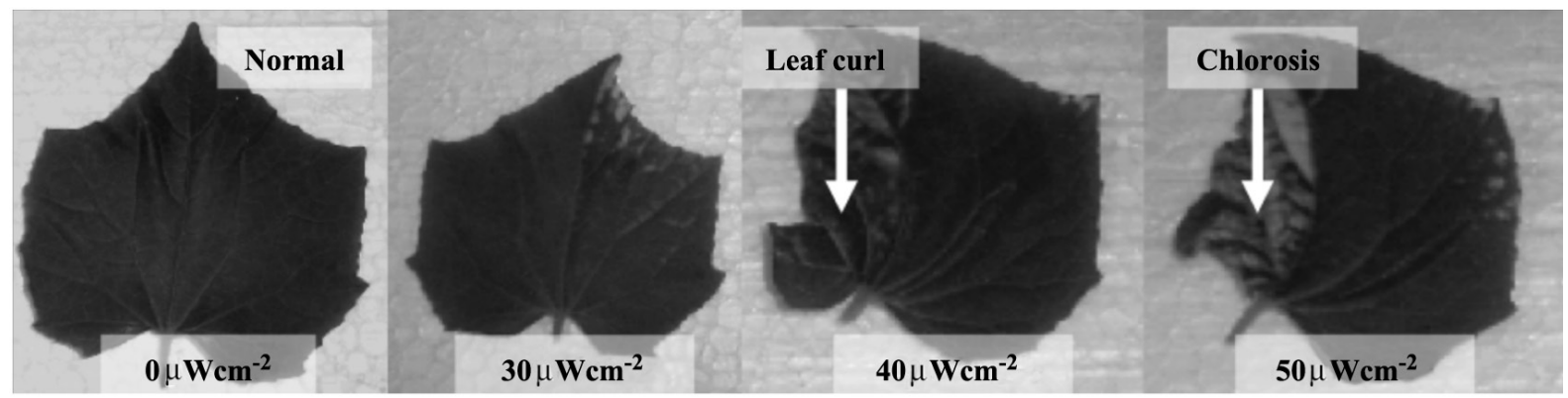

Figure 1. Cucumber leaves cv. Poinsett 76 exposed to distinct intensities of ultraviolet B radiation with leaf curl and chlorosis. 


\section{Growth and morphology}

Table 4 shows how growth and the morphology of each cultivar were affected when considering the effect of overall radiation using the mean values obtained in each one of the UV-B radiation intensities applied. 'Laura' presented greater development of leaf area with UV-B radiation, $36 \%$ greater than cvs. Sprint 440 , Dasher II, and Exocet, and more than $50 \%$ greater than cvs. Poinsett 76 and Marketmore 76. 'Laura' seedling height was significantly greater $(\mathrm{p} \leq 0.05)$ than the height of cvs. Sprint 440, Poinsett 76, and Marketmore 76 with 31, 67, and 68\%, respectively. The cultivars Dasher II and Exocet obtained a mean height of 16.7, 13\% lower than the height of cv. Laura. Cultivars maintained the same behavior for leaf area and seedling height response (Figure 2 ) which can be due to two effects. First, inhibiting the tubulin enzyme provoking a decrease in cellular division (Nogués et al., 1998; An et al., 2004), and secondly, photo-oxidizing the auxin hormone responsible for the extensibility of the cell wall (Hollósy, 2002; Kakani et al., 2003).

Aerial fresh weight of cv. Laura was significantly greater than the values for cvs. Exocet, Poinsett 76, and Marketmore 76 with 41,89 , and $127 \%$, respectively
(Figure 3). Cultivars with a greater mean value for fresh root weight were 'Laura' and 'Dasher II' with 122 and 198\% more than 'Poinsett 76' and 'Marketmore 76', respectively. As for total fresh weight, calculated as the sum of the means of each cultivar, the behavior was equal to the fresh root weight with cvs. 'Laura' and 'Dasher II' as those with the greatest seedling total fresh weight surpassing 'Poinsett 76' and 'Marketmore 76' by 88 and $129 \%$, respectively (Table 4 ).

'Laura' presented the greatest dry weight of the aerial part which was significantly greater $(\mathrm{p} \leq 0.05)$ than 'Sprint 440', 'Exocet', 'Poinsett 76', and 'Marketmore 76' with $57,65,135$, and $300 \%$, respectively (Table 4, Figure 3). Cultivars with the greatest biomass accumulation for root dry weight were 'Laura' and 'Dasher II' surpassing cvs. Poinsett 76 and Marketmore 76 by $125 \%$. The reduction of fresh weight in the most sensitive cultivars would be associated with losses in cell turgence pressure (Hopkins et al., 2002) and a decrease in the degree of opening and stomatal density (Kakani et al., 2003).

Table 5 shows how growth and morphology were affected in each UV-B radiation intensity level using the mean values of each cultivar. Leaf area of the seedlings exposed to $30 \mu \mathrm{W} \mathrm{cm} \mathrm{cm}^{-2}$ presented a $30 \%$ reduction, but

Table 2. Level of damage expressed as chlorosis in six cucumber cultivars exposed to distinct UV-B radiation intensities.

\begin{tabular}{|c|c|c|c|c|c|c|c|c|c|c|c|c|}
\hline \multirow[b]{3}{*}{ Cultivars } & \multicolumn{12}{|c|}{ Treatments } \\
\hline & \multicolumn{3}{|c|}{$0 \mu \mathrm{W} \mathbf{c m}^{-2}$} & \multicolumn{3}{|c|}{$30 \mu \mathrm{W} \mathbf{c m}^{-2}$} & \multicolumn{3}{|c|}{$40 \mu \mathrm{W} \mathrm{cm}^{-2}$} & \multicolumn{3}{|c|}{$50 \mu \mathrm{W} \mathrm{cm}^{-2}$} \\
\hline & $\begin{array}{c}\text { Leaf } \\
1\end{array}$ & $\begin{array}{c}\text { Leaf } \\
2\end{array}$ & $\begin{array}{c}\text { Leaf } \\
3 \\
\end{array}$ & $\begin{array}{c}\text { Leaf } \\
1 \\
\end{array}$ & $\begin{array}{c}\text { Leaf } \\
2 \\
\end{array}$ & $\begin{array}{c}\text { Leaf } \\
3 \\
\end{array}$ & $\begin{array}{c}\text { Leaf } \\
1 \\
\end{array}$ & $\begin{array}{c}\text { Leaf } \\
2 \\
\end{array}$ & $\begin{array}{c}\text { Leaf } \\
3 \\
\end{array}$ & $\begin{array}{c}\text { Leaf } \\
1\end{array}$ & $\begin{array}{c}\text { Leaf } \\
2\end{array}$ & $\begin{array}{c}\text { Leaf } \\
3 \\
\end{array}$ \\
\hline Laura & 1 & 1 & 1 & 2 & 2 & 2 & 2 & 2 & 1 & 2 & 2 & 1 \\
\hline Sprint 440 & 1 & 1 & 1 & 2 & 2 & 1 & 2 & 2 & 2 & 2 & 2 & 1 \\
\hline Dasher II & 1 & 1 & 1 & 2 & 2 & 1 & 3 & 2 & 1 & 2 & 2 & 2 \\
\hline Exocet & 1 & 1 & 1 & 2 & 1 & 1 & 2 & 2 & 2 & 2 & 2 & 1 \\
\hline Poinsett 76 & 1 & 1 & 1 & 4 & 2 & 1 & 4 & 3 & 2 & 3 & 4 & 2 \\
\hline $\begin{array}{l}\text { Market } \\
\text { more } 76\end{array}$ & 1 & 1 & 1 & 1 & 1 & 1 & 1 & 1 & 1 & 2 & 2 & 1 \\
\hline
\end{tabular}

Table 3. Presence (P) and absence (A) of leaf curl in the cultivars under distinct intensities of UV-B radiation.

\begin{tabular}{lcccc}
\hline & \multicolumn{3}{c}{ Treatments } \\
\cline { 2 - 5 } Cultivars & $\mathbf{0} \boldsymbol{\mu} \mathbf{W} \mathbf{~ c m}^{-2}$ & $\mathbf{3 0} \boldsymbol{\mu W} \mathbf{~ c m}^{-2}$ & $\mathbf{4 0} \boldsymbol{\mu} \mathbf{W} \mathbf{~ m}^{-2}$ & $\mathbf{5 0} \boldsymbol{\mu} \mathbf{W ~ \mathbf { ~ m } ^ { - 2 }}$ \\
\hline Laura & $\mathrm{A}$ & $\mathrm{A}$ & $\mathrm{A}$ & $\mathrm{A}$ \\
Sprint 440 & $\mathrm{~A}$ & $\mathrm{~A}$ & $\mathrm{P}(3)$ & $\mathrm{P}(1)$ \\
Dasher II & $\mathrm{A}$ & $\mathrm{A}$ & $\mathrm{P}(2)$ & $\mathrm{A}$ \\
Exocet & $\mathrm{A}$ & $\mathrm{P}(2)$ & $\mathrm{A}$ & $\mathrm{A}$ \\
Poinsett 76 & $\mathrm{~A}$ & $\mathrm{~A}$ & $\mathrm{P}(2)$ & $\mathrm{P}(1,2,3)$ \\
Marketmore 76 & $\mathrm{~A}$ & $\mathrm{~A}$ & $\mathrm{~A}$ & $\mathrm{~A}$
\end{tabular}

Parentheses indicate leaf curl, leaf 1 forming first on the cotyledons and successively in height. 

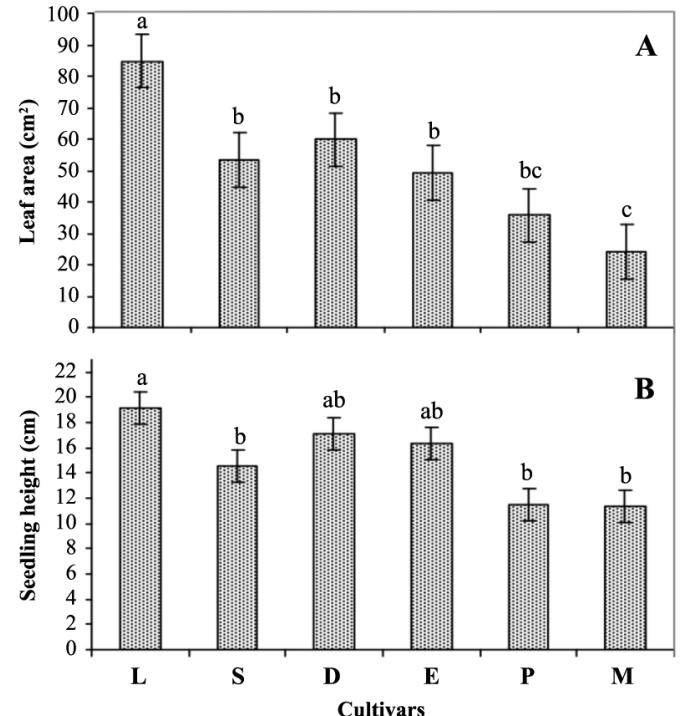

L: Laura; S: Sprint 440; D: Dasher II; E: Exocet; P: Poinsett 76; M: Marketmore 76.

Lower-case letters indicate significant statistical differences among cultivars $(\mathrm{p} \leq 0.05)$.

\section{Figure 2. Effect of cultivar on leaf area (A) and seedling} height (B).

for the highest radiation intensities (40 and $50 \mu \mathrm{W} \mathrm{cm}{ }^{-2}$ ), the reduction was only $11 \%$ without any differences $(\mathrm{p} \geq$ $0.05)$ in relation to the control. No differences $(p \geq 0.05)$ were observed with regards to seedling height, indicating that UV-B radiation did not generate any effect on seedling height, a fact also observed by Zhao et al. (2003) in cotton, but in cucumber, reports by Teklemariam and Blake (2003) and Wang et al. (2007) show a decrease in seedling height as a result of oxidative damage provoked by $\mathrm{UV}-\mathrm{B}$ radiation.

The distinct UV-B radiation intensities $(30,40$, and $\left.50 \mu \mathrm{W} \mathrm{cm}^{-2}\right)$ and control $\left(0 \mu \mathrm{W} \mathrm{cm} \mathrm{cm}^{-2}\right)$ did not produce

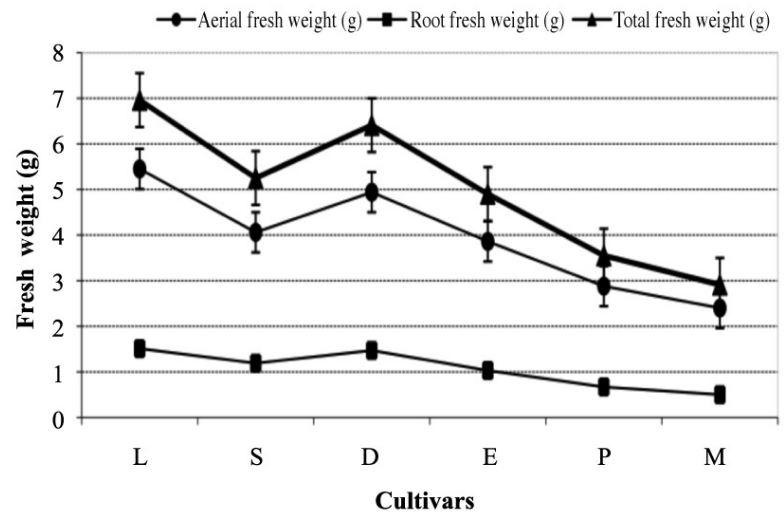

any differences $(\mathrm{p} \leq 0.05)$, neither in seedling fresh weight nor in dry weight (Table 5). However, this does not concur with the report by Wang et al. (2007) who informed decreases in fresh and dry weights of cucumber exposed to supplementary conditions of UV-B radiation.

\section{UV-B absorbing compounds and flavonoids}

'Laura' presented the highest content of UV-B absorbing compounds and flavonoids surpassing cv. Poinsett by 51 and 54\%, respectively. UV-B absorbing compounds in 'Laura' surpassed 'Dasher II' and 'Exocet' by 29\%, 'Sprint 440' and 'Marketmore 76' by 37\%. Flavonoid content of 'Sprint 440', 'Dasher II', 'Exocet', and 'Marketmore 76' did not present any differences (Table 4).

Although the content of UV-B absorbing compounds and flavonoids (Table 5) of the seedlings did not present any significant differences $(\mathrm{p} \leq 0.05)$ between the distinct intensities, and these values were always higher than the control (31\%), this response was also observed by Allen et al. (1998). Synthesis of these compounds is induced by UV-B radiation that stimulates the genetic expression of these pigments (Long et al., 2003). Furthermore, regulation of their biosynthesis can involve multiple photoreceptors including phytochromes that absorb blue light, and one or more UV photoreceptors (Mazza et al., 2000).

The increase of flavonoid production in the leaf epidermis is one of the most important defense mechanisms (Skórska, 2000) since it impedes UV-B radiation from passing to the most internal part of the mesophile thus avoiding the negative effect on photosynthesis (Treutter, 2006). These compounds form a screen that absorbs between $88-98 \%$ of incident UV-B radiation (Nybakken et al., 2004), reducing damage to DNA and to the photosystem II between 20 and $57 \%$

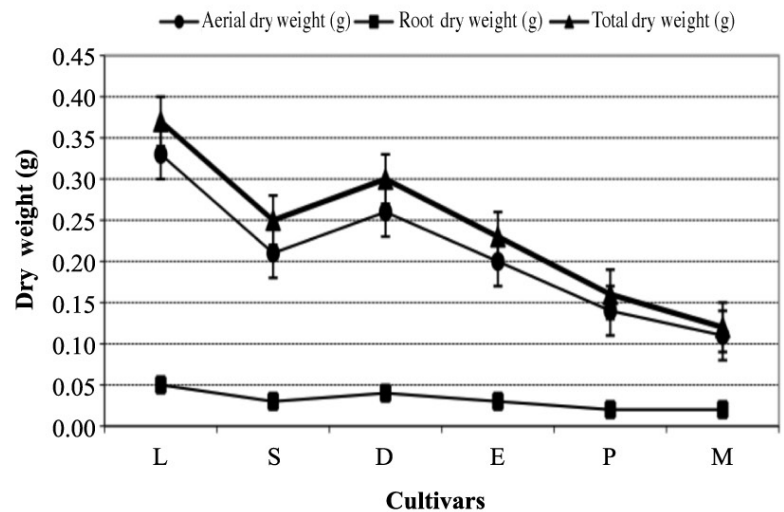

L: Laura; S: Sprint 440; D: Dasher II; E: Exocet; P: Poinsett 76; M: Marketmore 76.

Figure 3. Effect of cultivar on fresh and dry weight of aerial part, root, and total $(p \leq 0.05)$. 
Table 4. Mean values of morphological and growth variables and leaf pigments studied in seedlings of six cucumber cultivars.

\begin{tabular}{lcccccc}
\hline & \multicolumn{5}{c}{ Cultivars } \\
\cline { 2 - 7 } Parameters & Laura & Sprint 440 & Dasher II & Exocet & Poinsett 76 & Marketmore 76 \\
\hline Leaf area, $\mathrm{cm}^{2}$ & $84.80 \pm 5.78 \mathrm{a}$ & $53.30 \pm 5.78 \mathrm{~b}$ & $59.50 \pm 5.78 \mathrm{~b}$ & $49.30 \pm 5.78 \mathrm{~b}$ & $35.70 \pm 5.78 \mathrm{bc}$ & $24.10 \pm 5.78 \mathrm{c}$ \\
Seedling height, $\mathrm{cm}$ & $19.20 \pm 1.18 \mathrm{a}$ & $14.60 \pm 1.18 \mathrm{~b}$ & $17.10 \pm 1.18 \mathrm{ab}$ & $16.30 \pm 1.18 \mathrm{ab}$ & $11.50 \pm 1.18 \mathrm{~b}$ & $11.40 \pm 1.18 \mathrm{~b}$ \\
Aerial FW, g & $5.45 \pm 0.44 \mathrm{a}$ & $4.06 \pm 0.44 \mathrm{ab}$ & $4.94 \pm 0.44 \mathrm{ab}$ & $3.86 \pm 0.44 \mathrm{~b}$ & $2.88 \pm 0.44 \mathrm{~b}$ & $2.40 \pm 0.44 \mathrm{~b}$ \\
Root FW,g & $1.51 \pm 0.18 \mathrm{a}$ & $1.19 \pm 0.18 \mathrm{ab}$ & $1.47 \pm 0.18 \mathrm{ab}$ & $1.03 \pm 0.18 \mathrm{ab}$ & $0.67 \pm 0.18 \mathrm{~b}$ & $0.50 \pm 0.18 \mathrm{~b}$ \\
Total FW,g & $6.96 \pm 0.59 \mathrm{a}$ & $5.25 \pm 0.59 \mathrm{ab}$ & $6.41 \pm 0.59 \mathrm{ab}$ & $4.90 \pm 0.59 \mathrm{ab}$ & $3.55 \pm 0.59 \mathrm{~b}$ & $2.91 \pm 0.59 \mathrm{~b}$ \\
Aerial DW, g & $0.33 \pm 0.03 \mathrm{a}$ & $0.21 \pm 0.03 \mathrm{~b}$ & $0.26 \pm 0.03 \mathrm{ab}$ & $0.20 \pm 0.03 \mathrm{bc}$ & $0.14 \pm 0.03 \mathrm{bc}$ & $0.11 \pm 0.03 \mathrm{c}$ \\
Root DW,g & $0.05 \pm 0.00 \mathrm{a}$ & $0.03 \pm 0.00 \mathrm{ab}$ & $0.04 \pm 0.00 \mathrm{ab}$ & $0.03 \pm 0.00 \mathrm{ab}$ & $0.02 \pm 0.00 \mathrm{~b}$ & $0.02 \pm 0.00 \mathrm{~b}$ \\
Total DW,g & $0.37 \pm 0.03 \mathrm{a}$ & $0.25 \pm 0.03 \mathrm{~b}$ & $0.30 \pm 0.03 \mathrm{ab}$ & $0.23 \pm 0.03 \mathrm{~b}$ & $0.16 \pm 0.03 \mathrm{bc}$ & $0.12 \pm 0.03 \mathrm{c}$ \\
$\mathrm{A}_{300} \mathrm{~cm}^{-2}(\mathrm{AC} \mathrm{UV}-\mathrm{B})$ & $1.07 \pm 0.05 \mathrm{a}$ & $0.68 \pm 0.05 \mathrm{bc}$ & $0.73 \pm 0.05 \mathrm{~b}$ & $0.78 \pm 0.05 \mathrm{~b}$ & $0.53 \pm 0.06 \mathrm{c}$ & $0.67 \pm 0.05 \mathrm{bc}$ \\
$\mathrm{A}_{360} \mathrm{~cm}^{-2}(\mathrm{FL})$ & $0.66 \pm 0.03 \mathrm{a}$ & $0.41 \pm 0.03 \mathrm{~b}$ & $0.43 \pm 0.03 \mathrm{~b}$ & $0.47 \pm 0.03 \mathrm{~b}$ & $0.31 \pm 0.04 \mathrm{c}$ & $0.40 \pm 0.03 \mathrm{~b}$ \\
Chlorophyll $a, \mathrm{mg} \mathrm{m}^{-2}$ & $331.70 \pm 7.88 \mathrm{a}$ & $329.10 \pm 7.88 \mathrm{a}$ & $339.70 \pm 7.88 \mathrm{a}$ & $330.30 \pm 7.88 \mathrm{a}$ & $290.40 \pm 8.21 \mathrm{~b}$ & $321.40 \pm 7.88 \mathrm{a}$ \\
Chlorophyll $b, \mathrm{mg} \mathrm{m}^{-2}$ & $146.40 \pm 5.85 \mathrm{ab}$ & $148.50 \pm 5.85 \mathrm{ab}$ & $152.00 \pm 5.85 \mathrm{a}$ & $147.00 \pm 5.85 \mathrm{ab}$ & $126.60 \pm 6.09 \mathrm{~b}$ & $137.90 \pm 5.85 \mathrm{ab}$ \\
Chlorophyll $\mathrm{a} / \mathrm{b}$ & $2.28 \pm 0.04 \mathrm{a}$ & $2.24 \pm 0.04 \mathrm{a}$ & $2.26 \pm 0.04 \mathrm{a}$ & $2.28 \pm 0.04 \mathrm{a}$ & $2.36 \pm 0.05 \mathrm{a}$ & $2.35 \pm 0.04 \mathrm{a}$ \\
Carotenoids, $\mathrm{mg} \mathrm{m}^{-2}$ & $56.63 \pm 1.26 \mathrm{a}$ & $51.63 \pm 1.26 \mathrm{abc}$ & $53.58 \pm 1.26 \mathrm{ab}$ & $51.69 \pm 1.26 \mathrm{bc}$ & $48.28 \pm 1.32 \mathrm{c}$ & $54.31 \pm 1.26 \mathrm{ab}$ \\
\hline
\end{tabular}

Distinct letters in the row indicate significant differences between cultivars ( $\mathrm{p} \leq 0.05)$; \pm standard error; FW: fresh weight; DW: dry weight; AC: absorbing compounds; FL: flavonoids.

without hindering the passing of radiation required by photosynthesis (Cockell and Knowland, 1999). Furthermore, flavonoids act as antioxidants repairing o preventing the indirect damage caused by UV-B radiation (Treutter, 2006).

\section{Chlorophyll $\boldsymbol{a}$ and $\boldsymbol{b}$, and carotenoids}

'Poinsett' presented the lowest chlorophyll $a$ content ( $\mathrm{p} \leq$ 0.05 ) in relation to other cultivars. The cultivar with the highest chlorophyll $b$ content was 'Dasher II', surpassing 'Laura', 'Sprint 440', 'Exocet', and 'Marketmore 76', and showing a 17\% difference with 'Dasher II' (Table 4). The relationship of both chlorophylls did not present any significant differences.

Chlorophyll $a$ content in seedlings exposed to $30 \mu \mathrm{W}$ $\mathrm{cm}^{-2}$ UV-B radiation presented the lowest value being significantly lower at the highest radiation intensity $(50 \mu \mathrm{W} \mathrm{cm}-2)$, approximately $8 \%$. Considering only the presence of UV-B radiation, this increased chlorophyll $b$ content, $7 \%$ with the 30 and $40 \mu \mathrm{W} \mathrm{cm}-2$ intensities and $15 \%$ with $50 \mu \mathrm{W} \mathrm{cm}{ }^{-2}$ in relation to the control showed a positive effect in its synthesis.

The greatest chlorophyll $a / b$ ratio was recorded in the control treatment due to the positive effect in chlorophyll $b$ presenting a ratio of $4 \%$ more than the 30 and $40 \mu \mathrm{W}$ $\mathrm{cm}^{-2}$ intensities. The lowest ratio was observed with the $50 \mu \mathrm{W} \mathrm{cm}{ }^{-2}$ intensity with a percentage difference of 4 to $6 \%$ in relation to 30 and $40 \mu \mathrm{W} \mathrm{cm}-2$ treatments (Table 5).
According to Day and Demchik (1996), the highest UV-B radiation levels do not necessarily produce lower chlorophyll $a$ content, but that moderate levels can be more damaging since they would require a higher UV-B radiation level to obtain the plant's protection responses. The increase in chlorophylls can also explain how the indirect effect of protection against damage provoked by UV-B radiation, synthesis of phenolic compounds (UVB absorbing compounds and flavonoids) are generated under high intensities which act as a barrier reducing UV-B radiation penetration (Caldwell y Britz, 2006), and avoiding the degradation of D1 and D2 proteins that make up the pigment-protein complex of the photosystem II stabilizing and increasing chlorophyll synthesis (Jansen et al., 1998). The increase of chlorophyll $b$ would be associated with a certain level of acclimatization of UV-B radiation since this pigment is closely related to the pigment-protein complex (LHCII) which mostly has chlorophyll $b$ in its structure and is present in the photosystem II (Kitajima y Hogan, 2003). Reduction of the LHCII protein activity produced by chlorophyll $b$ degradation facing high UV-B radiation levels (Mackerness et al., 1998) would be decisive to recognize the sensitivity of a species to UV-B radiation.

In relation to the chlorophyll $a / b$ ratio, Smith et al. (2000) report that the normal response of this ratio facing high UV-B radiation intensities would be a decrease in the ratio, contrary to what was obtained in this study, mainly 
Table 5. Means of morphological and growth variables, and leaf pigments in cucumber seedlings exposed to distinct intensities of ultraviolet-B radiation.

\begin{tabular}{|c|c|c|c|c|}
\hline \multirow[b]{2}{*}{ Parameters } & \multicolumn{4}{|c|}{ Intensity of ultraviolet B radiation } \\
\hline & $0 \mu \mathrm{W} \mathbf{c m}^{-2}$ & $30 \mu \mathrm{W}$ cm$^{-2}$ & $40 \mu \mathrm{W} \mathrm{cm}^{-2}$ & $50 \mu \mathrm{W} \mathbf{~ c m}^{-2}$ \\
\hline Leaf area, $\mathrm{cm}^{2}$ & $58.80 \pm 11.50 \mathrm{a}$ & $40.90 \pm 11.50 b$ & $55.30 \pm 11.50 \mathrm{ab}$ & $49.50 \pm 11.50 \mathrm{ab}$ \\
\hline Seedling height, $\mathrm{cm}$ & $16.05 \pm 2.36 \mathrm{a}$ & $14.40 \pm 2.36 \mathrm{a}$ & $15.11 \pm 2.36 \mathrm{a}$ & $14.57 \pm 2.36 \mathrm{a}$ \\
\hline Aerial FW, g & $4.16 \pm 0.87 \mathrm{a}$ & $3.55 \pm 0.87 \mathrm{a}$ & $3.98 \pm 0.87 \mathrm{a}$ & $4.04 \pm 0.87 \mathrm{a}$ \\
\hline Root FW, g & $1.19 \pm 0.35 \mathrm{a}$ & $0.75 \pm 0.35 a$ & $1.18 \pm 0.35 \mathrm{a}$ & $1.13 \pm 0.35 \mathrm{a}$ \\
\hline Total FW, g & $5.36 \pm 1.18 \mathrm{a}$ & $4.30 \pm 1.18 \mathrm{a}$ & $5.16 \pm 1.18 \mathrm{a}$ & $5.17 \pm 1.18 \mathrm{a}$ \\
\hline Aerial DW, $\mathrm{g}$ & $0.23 \pm 0.05 \mathrm{a}$ & $0.18 \pm 0.05 a$ & $0.22 \pm 0.05 a$ & $0.21 \pm 0.05 \mathrm{a}$ \\
\hline Root DW, g & $0.03 \pm 0.01 \mathrm{a}$ & $0.02 \pm 0.01 \mathrm{a}$ & $0.04 \pm 0.01 \mathrm{a}$ & $0.03 \pm 0.01 \mathrm{a}$ \\
\hline Total DW, g & $0.26 \pm 0.06 \mathrm{a}$ & $0.20 \pm 0.06 \mathrm{a}$ & $0.26 \pm 0.06 \mathrm{a}$ & $0.24 \pm 0.06 \mathrm{a}$ \\
\hline $\mathrm{A}_{300} \mathrm{~cm}^{-2}(\mathrm{AC} \mathrm{UV}-\mathrm{B})$ & $0.57 \pm 0.04 \mathrm{a}$ & $0.73 \pm 0.04 b$ & $0.87 \pm 0.04 \mathrm{~b}$ & $0.82 \pm 0.04 b$ \\
\hline $\mathrm{A}_{360} \mathrm{~cm}^{-2}(\mathrm{FL})$ & $0.33 \pm 0.03 \mathrm{a}$ & $0.44 \pm 0.03 b$ & $0.51 \pm 0.03 b$ & $0.50 \pm 0.03 b$ \\
\hline Chlorophyll $a, \mathrm{mg} \mathrm{m}^{-2}$ & $315.00 \pm 6.44 \mathrm{ab}$ & $309.50 \pm 6.61 \mathrm{a}$ & $333.10 \pm 6.44 \mathrm{bc}$ & $337.50 \pm 6.44 c$ \\
\hline Chlorophyll $b, \mathrm{mg} \mathrm{m}^{-2}$ & $133.50 \pm 4.77 \mathrm{a}$ & $137.20 \pm 4.91 \mathrm{ab}$ & $148.60 \pm 4.77 \mathrm{ab}$ & $153.00 \pm 4.77 b$ \\
\hline Chlorophyll $a / b$ & $2.37 \pm 0.04 \mathrm{a}$ & $2.29 \pm 0.04 \mathrm{ab}$ & $2.28 \pm 0.04 \mathrm{ab}$ & $2.23 \pm 0.04 b$ \\
\hline Carotenoids, $\mathrm{mg} \mathrm{m}^{-2}$ & $50.86 \pm 1.03 \mathrm{a}$ & $51.57 \pm 1.06 \mathrm{a}$ & $53.06 \pm 1.03 \mathrm{ab}$ & $55.26 \pm 1.03 b$ \\
\hline
\end{tabular}

Distinct letters in the row indicate significant differences between cultivars $(\mathrm{p} \leq 0.05)$; \pm standard error; FW: fresh weight; DW: dry weight; AC: absorbing compounds; FL: flavonoids.

due to the increase of chlorophyll $b$ content previously described.

Significant ( $\mathrm{p} \leq 0.05)$ differences can be observed in the carotenoid content between cvs. Laura and Poinsett 76 (Table 4), the first being 17\% higher in carotenoid content. The greater carotenoid content was in the $50 \mu \mathrm{W} \mathrm{cm}-2$ level which was $8 \%$ higher than the mean value between the control treatment and $30 \mu \mathrm{W} \mathrm{cm}{ }^{-2}$ intensities (Table 5). The high level of carotenoids in high UV-B radiation intensities have been reported by Caldwell and Britz (2006) who indicate that it would be related to an indirect defense strategy responding to a high UV-B radiation level. However, it has been observed that with high UV-B radiation intensities, reductions of the carotenoid contents are also produced generating damage or alterations in the photosynthetic apparatus (Meijkamp, 2006).

\section{CONCLUSIONS}

Under the conditions of this study, it was determined that cv. Poinsett 76 is the most sensitive with a marked leaf curl and chlorosis followed by cv. Marketmore 76 . This was provoked by a lower concentration of UV-B absorbing compounds and these inadequate quantities would not effectively filter UV-B radiation. Parameters associated with the cultivars would be effective in the determination of cucumber seedling photosensitivity.

Cultivars with the greatest leaf development and the highest UV-B absorbing compounds and flavonoids would respond better to the negative effects of UV-B radiation.

Chlorophyll $a$ and $b$ would play an important role in the indirect protection of the photosynthetic apparatus as well as carotenoids.

All the analyzed parameters could be used as response indicators to UV-B radiation, but not as sensitivity indicators of UV-B radiation.

\section{ACKNOWLEDGEMENTS}

Antarctic Institutional Program of the Universidad de Chile (PIA), Vicerectory of Research and Development. Instituto Antártico Chileno (INACH), Ministry of Foreign Affairs. Project INACH 164-02: Effect of UV-B radiation on plant species.

\section{RESUMEN}

Fotosensibilidad de plantines de pepino de ensalada (Cucumis sativus L.) expuestos a radiación ultravioleta del tipo B. La radiación ultravioleta tipo B (UV-B) ha ido aumentando su intensidad a nivel de la superficie terrestre producto de la disminución del ozono estratosférico, provocando efectos negativos en una amplia gama de especies, observándose alteraciones morfológicas, fisiológicas y bioquímicas. En este trabajo se estudió la fotosensibilidad intraespecífica de plantines de pepino de ensalada (Cucumis sativus L.) 
expuestos a radiación UV-B. Se evaluaron seis cultivares comerciales: Laura, Sprint 440, Dasher II, Exocet, Poinsett 76 y Marketmore 76, en condiciones ambientales controladas en invernadero con sistema hidropónico tipo "sandwich" en solución nutritiva Hoagland II. Los plantines recibieron radiación UV-B durante 18 días desde cotiledones expandidos hasta tercera hoja verdadera. Los plantines fueron separados en tres grupos y cada uno recibió una dosis de UV-B diferente (30, 40 y $50 \mu \mathrm{W} \mathrm{cm}$ cm $\left.^{-2} \mathrm{UV}-\mathrm{B}\right)$ entre las 11:40-15:40 h. Se evaluaron variables de crecimiento, morfológicas, y de acumulación de pigmentos fotosintéticos y pigmentos absorbedores de UV-B. 'Laura' fue el menos afectado por clorosis y tuvo ausencia total de enrollamiento foliar, en cambio, 'Poinsett 76' fue el más afectado en las intensidades de 40 y $50 \mu \mathrm{W} \mathrm{cm}$ c $^{-2}$. En área foliar y altura de plantín, 'Marketmore 76' y 'Poinsett 76' obtuvieron los más bajos valores. 'Laura' obtuvo el mayor valor en peso fresco y en peso seco de plantín. 'Poinsett 76' obtuvo el menor contenido de pigmentos absorbedores de UV-B, siendo un $53 \%$ inferior al obtenido por 'Laura' . 'Poinsett 76' obtuvo menor contenido de clorofila y carotenoides. Los parámetros usados fueron indicadores de respuesta a la radiación UV-B, pero no resultarían buenos indicadores de sensibilidad a la radiación UV-B en plantines de pepino de ensalada.

Palabras clave: radiación UV-B, Cucumis sativus, clorofila, compuestos absorbedores UV-B, clorosis.

\section{LITERATURE CITED}

Allen, D., S. Nogués, and N. Baker. 1998. Ozone depletion and increased UV-B radiation: is there a real threat to photosynthesis? J. Exp. Bot. 49:1775-1788.

An, L., G. Liu, H. Zhang, T. Chen, Y. Liu, H. Feng, et al. 2004. Effect of enhanced UV-B radiation on polyamine content and membrane permeability in cucumber leaves. Russ. J. Plant Physiol. 51:658-662.

Borisova, T., S. Bugaje, N. Meshkova, and P. Viasov. 2001. Heat shock increases the tolerance of plants to UV-B radiation: 1. Growth, development, and water supply to tissues. Russ. J. Plant Physiol. 48:507-513.

Cabrera, S., S. Bozzo, and H. Fuenzalida. 1995. Variations in UV radiation in Chile. J. Photochem. Photobiol. 28:137-142.

Caldwell, C., and S. Britz. 2006. Effect of supplemental ultraviolet radiation on the carotenoid and chlorophyll composition of green house-grown leaf lettuce (Lactuca sativa L.) cultivars. J. Food Compos. Anal. 19:637-644.
Cockell, C., and J. Knowland. 1999. Ultraviolet radiation screening compounds. Biol. Rev. 74:311-345.

Day, T., and S. Demchik. 1996. Influence of enhanced UV-B radiation on biomass allocation and pigment concentrations in leaves and reproductive structures of greenhouse-grown Brassica rapa. Vegetatio 127:109-116.

Faúndez, N. 2004. Fotosensibilidad de plantines de maíz expuestos a radiación ultravioleta del tipo B. 74 p. Tesis de Ingeniero Agrónomo. Universidad de Chile, Facultad de Ciencias Agronómicas, Santiago, Chile.

Feng, H., L. An, T. Chen, W. Qiang, S. Xu, M. Zhang, et al. 2003. The effect of enhanced ultraviolet-B radiation on growth, photosynthesis and stable carbon isotope composition (iC) of two soybean cultivars (Glycine $\max$ ) under field conditions. Environ. Exp. Bot. 49:1-8.

Frohnmeyer, H., and D. Staiger. 2003. Ultraviolet-B radiation-mediated responses in plants. Balancing damage and protection. Plant Physiol. 133:1420-1428.

Hilal, M., M. Parrado, M. Rosa, M. Gallardo, L. Orce, E. Massa, et al. 2004. Epidermal lignin deposition in quinoa cotyledons in response to UV-B radiation. Photochem. Photobiol. 79:205-210.

Hoagland, D., and D. Arnon. 1950. The water-culture method for growing plants without soil. Calif. Agric. Exp. Stn. Circ. 347.

Hollósy, F. 2002. Effect of ultraviolet radiation on plant cells. Micron 33:179-197.

Hopkins, L., M. Bond, and A. Tobin. 2002. Ultraviolet-B radiation reduces the rates of cell division and elongation in the primary leaf of wheat (Triticum aestivum L. cv. Maris Huntsman). Plant Cell Environ. 25:617-624.

Hunt, J., and D. McNeil. 1998. Nitrogen status affects UV-B sensitivity of cucumber. Aust. J. Plant Physiol. 25:79-86.

Jansen, M., V. Gava, and B. Greenberg. 1998. Higher plants and UV-B radiation: balancing damage, repair and acclimation. Trends Plant Sci. 3:131-135.

Kakani, V., K. Reddy, D. Zhao, and K. Sailaja. 2003. Field crop response to ultraviolet-B radiation: A review. Agric. For. Meteorol. 120:191-218.

Kitajima, K., and K. Hogan. 2003. Increases of chlorophyll $a / b$ ratios during acclimation of tropical woody seedling to nitrogen limitation and high light. Plant Cell Environ. 26:857-865.

Kramer, G., H. Norman, D. Krizek, and R. Mirecki. 1991. Influence of UV-B radiation on polyamines, lipid peroxidation and membrane lipids in cucumber. Phytochem. 30:2101-2108. 
Krizek, D., G. Kramer, A. Upadhyaya, and R. Mirecki. 1993. UV-B response of cucumber seedlings grown under metal halide and high pressure sodium/deluxe lamps. Physiol. Plant. 88:350-358.

Krizek, D., E. Middleton, R. Sandhu, and M. Kim. 2001. Evaluating UV-B effects and EDU protection in cucumber leaves using fluorescence images and fluorescence emission spectra. J. Plant Physiol. 158:41-53.

Kumagai, T., J. Ilidema, I. Kang, and T. Sato. 2001. Effects of supplemental UV-B radiation on the growth and yield of two cultivars of Japanese lowland rice (Oryza sativa L.) under the field in a cool rice-growing region of Japan. Agric. Ecosyst. Environ. 83:201-208.

Lau, T.S., E. Eno, G. Goldstein, C. Smith, and D. Christopher. 2006. Ambient levels of UV-B in Hawaii combined with nutrient deficiency decreased photosynthesis in near-isogenic maize lines varying in leaf flavonoids: Flavonoids decrease photoinhibition in plants exposed to UV-B. Photosynthetica 44:394403.

Lichtenthaler, H., and A. Wellburn. 1983. Determination of total carotenoids and chlorophylls a and b of leaf extract in different solvents. Biochem. Soc. Trans. 603:591-592.

Long, L., H. Patel, W. Cory, and A. Stapleton. 2003. The maize epicuticular wax layer provides UV protection. Funct. Plant Biol. 30:75-81.

Mackerness, S., S. Surplus, B. Jordan, and B. Thomas. 1998. Effects of supplementary ultraviolet-B radiation on photosynthetic transcripts at different stages of leaf development and light levels in pea (Pisum sativum L.): Role of active oxygen species and antioxidant enzymes. Photochem. Photobiol. 68:88-96

Mazza, C., H. Boccalandro, C. Giordano, D. Battista, A. Scopel, and C. Ballaré. 2000. Functional significance and induction by solar radiation of ultravioletabsorbing sunscreens in field-grown soybean crops. Plant Physiol. 2:117-125.

McKenzie, R., L. Bjorn, A. Bais, and M. Ilyasad. 2003. Changes in biologically active ultraviolet radiation reaching the Earth`s surface. Photochem. Photobiol. 2:5-15.

Meijkamp, B. 2006. Multilevel UV-B attenuance. Morphological and chemicals adaptations of Vicia faba to ultravioleta-B radiation. 158 p. Ph.D. Thesis. Vrije Universiteit, Amsterdam, The Netherlands.
Musil, C., S. Chimphango, and F. Dakora. 2002. Effects of elevated ultraviolet-B radiation on native and cultivated plants of Southern Africa. Ann. Bot. (London) 90:127-137.

Nogués, S., D. Allen, J. Morison, and N. Baker. 1998. Ultraviolet-B radiation effects on water relations, leaf development, and photosynthesis in droughted pea plants. Plant Physiol. 117:173-181.

Nybakken, L., W. Bilger, U. Johanson, L. Björn, M. Zielke, and B. Solheim. 2004. Epidermal UV-screening in vascular plants from Svalbard (Norwegian Arctic). Polar Biol. 27:383-390.

Pinto, M., C. Lizana, C. Pastenes, A. Riquelme, y M. Berti. 2000. Efecto de la radiación ultravioleta-B sobre el crecimiento y la fotosíntesis de siete variedades de trigo (Triticum aestivum L.). Rev. Chil. Hist. Nat. 73:55-66.

Robberecht, R., and M. Caldwell. 1978. Leaf epidermal transmittance of ultraviolet radiation and its implications for plant sensitivity to ultraviolet radiation induced injury. Oecología 32:277-287.

Rowland, S.F. 2006. Stratospheric ozone depletion. Phil. Trans. R. Soc. B. 361:769-790.

Santos, I., F. Fidalgo, J. Almeida, and R. Salema. 2004. Biochemical and ultrastructural changes in leaves of potato plants grown under supplementary UV-B radiation. Plant Sci. 167:925-935.

Skórska, E. 2000. Responses of pea and triticale photosynthesis and growth to long-wave UV-B radiation. Biol. Plant. 43:129-131.

Smith, J., D. Burrit, and P. Bannister. 2000. Shoot dry weight, chlorophyll and UV-B-absorbing compounds as indicators of plant's sensitivity to UV-B radiation. Ann. Bot (London) 86:1057-1063.

Takahashi, S., N. Nakajima, H. Saji, and N. Kondo. 2002. Diurnal change of cucumber CPD photolyase gene (CsPHR) expression and its physiological role in growth under UV-B irradiation. Plant Cell Physiol. 43:342-349.

Teklemariam, T., and T. Blake. 2003. Effect of UV-B preconditioning on heat tolerance of cucumber (Cucumis sativus L.) Environ. Exp. Bot. 50:169-182.

Treutter, D. 2006. Significance of flavonoids in plant resistance: a review. Environ. Chem. Lett. 4:147157.

WMO. 2007. Scientific assessment of ozone depletion: 2006. Global Ozone Research and Monitoring Project-Report No 50.572 p. World Meteorological Organization (WMO), Geneva, Switzerland. 
Wang, S., S. Fan, Y. Kong, and C. Qingjun. 2007. Effect of light quality on the growth and photosynthetics characteristics of cucumber Cucumis sativus $\mathrm{L}$. under solar greenhouse. Acta Hort. (ISHS) 731:243251.

Zavala, J., and J. Botto. 2002. Impact of solar UV-B radiation on seedling emergence, chlorophyll fluorescence, and growth and yield of radish (Raphanus sativus). Funct. Plant Biol. 29:79-804.
Zhao, D., K. Reddy, V. Kakani, J. Read, and J. Sullivan. 2003. Growth and physiological response of cotton (Gossypium hirsutum L.) to elevated carbon dioxide and ultraviolet- $\mathrm{B}$ radiation under controlled environmental conditions. Plant Cell Environ. 26:771-782. 